\title{
Effect of Feeding Rate on Survival, Zootechnical Performance of Tilapia Oreochromis niloticus (Linnaeus, 1758) Brazil Strain Larvae Fed on 17- $\alpha$ - methyltestosterone Treated Feed
}

\author{
Issa Nahoua Ouattara, Claver Zea Bi Ue, Siaka Berte, and Bakagnan Kamagate
}

\section{ABSTRACT}

\begin{abstract}
This study was conducted to evaluate the feeding levels on survival, growth performance and feed utilization in the Brazil strain of Nile tilapia Oreochromis niloticus. Four (4) batches of larvae with mean initial weight $0.012 \pm 0.005 \mathrm{~g}$ and mean initial total length $9 \pm 0.003 \mathrm{~mm}$ were formed in triplicate, three per feeding rate. The rationing rates according to fry biomass applied in this trial were: batch 1: 50, 40, 30 and 25\%, batch 2: 40, 30,25 and $20 \%$, batch $3: 30,25,20$ and $18 \%$ and batch $4: 25,20,18$ and $15 \%$ of biomass. The different feeding rates were tested during the 1st, 2nd, 3rd and 4th week of larval rearing respectively. The fish were all fed a commercial feed (48\% protein) distributed manually at a frequency of 5 meals per day. After 28 days of rearing, the results show that apart from the survival rate, the other parameters such as final average weight, daily growth and food consumption index were affected by the different rationing rates tested. The larvae of batch 2 rationed at $40,30,25$ and $20 \%$ of their biomass during the 1st, 2nd, 3rd and 4th week of rearing respectively recorded significantly higher growth parameters (MWF: $1.092 \pm 0.027 \mathrm{~g}$ and DG: $0.038 \pm 0.000 \mathrm{~g})$ and a more interesting food converion ratio $(0.88)$ than the other batches of fry. From this study, it is concluded that an optimal feeding rate of $40,30,25$ and $20 \%$ of the larval biomass during the 1st, 2nd, 3rd and 4th week of rearing, respectively, should be applied in order to avoid either wastage or underfeeding of the subjects during hormone treatment with $17 \alpha$-methyltestosterone.
\end{abstract}

Keywords: feeding rate, hormone treatment, Nile tilapia, strain.
Published Online: September 21, 2021

ISSN: $2684-5199$

DOI: $10.24018 /$ ejbio.2021.2.5.222

Issa Nahoua Ouattara*

Natural Environment and Biodiversity Conservation Laboratory, Biosciences UFR, Félix Houphouët Boigny University, 22 BP 582 Abidjan 22, Côte d'Ivoire.

(e-mail: issanahoua@yahoo.fr)

Claver Zea Bi Ue

Natural Environment and Biodiversity Conservation Laboratory, Biosciences UFR, Félix Houphouët Boigny University, 22 BP 582 Abidjan 22, Côte d'Ivoire.

(e-mail: claverzea ${ }^{\circledR}$ gmail.com)

Siaka Berte

Natural Environment and Biodiversity Conservation Laboratory, Biosciences UFR, Félix Houphouët Boigny University, 22 BP 582 Abidjan 22, Côte d'Ivoire.

(e-mail: bertesia@yahoo.fr)

Bakagnan Kamagate

Natural Environment and Biodiversity Conservation Laboratory, Biosciences UFR, Félix Houphouët Boigny University, 22 BP 582 Abidjan 22, Côte d'Ivoire.

(e-mail: kambak486@gmail.com)

*Corresponding Author

\section{INTRODUCTION}

Aquaculture is considered one of the fastest growing activities in animal production. Freshwater fish accounts for the major part of aquaculture production. Tilapia farming follows the same evolutionary trend worldwide [1]. This evolution owes its success to the different processes of sexual inversion. Indeed, although the process of tilapia sex determination is under genetic control [2], sexual differentiation can be influenced by environmental conditions [3]. This influence can be related to the physicochemical parameter of the water [4] or to the controlled administration of steroid hormones [5]. The most common practice is the incorporation of androgens (30 to $70 \mathrm{mg}$ of $17 \alpha$ methyltestosterone $/ \mathrm{kg}$ ) in the feed during the larval rearing phase [6]. Several countries in Africa are already using this approach for good tilapia fry production [7]. However, this method is still in its infancy in Ivory Cost. Yet, according to [8], sex reversal is one of the most important phases in the rational rearing of Nile tilapia. Furthermore, the popularization of this method of sex reversal by hormone requires a certain knowledge of the technical follow-up of the fry, among which the rationing rate. This factor can influence the survival and growth of fry [9]. Indeed, according to [10], the rationing rate plays an important role in the regulation of food intake, faecal discharges as well as the growth of the fish. Moreover, an optimal feed intake not only promotes better zootechnical performance but also reduces the cost of production [11]. According to [12], the feed ration can vary according to several factors such as the size of the fish, its protein requirements and digestion capacity, the quality of the feed and the physicochemical conditions of the environment. Thus, daily rations according to tilapia fry size have been recommended by [13]. However, to our knowledge, no recommendation of daily ration in larval rearing of $O$. 
niloticus during hormonal treatment has been indicated. Furthermore, [14] point out that very few studies report on the zootechnical performance of $O$. niloticus specimens with an average initial weight of less than $2 \mathrm{~g}$. Thus, this study focused on the determination of optimal feeding rations in fry rearing was carried out in order to fill this scientific gap.

\section{MATERIALS AND METHODS}

\section{A. Experimental Protocol}

The experiments were carried out in a private fish farm, located between latitude $5^{\circ} 40^{\prime} \mathrm{N}$ and longitude $4^{\circ} 6^{\prime} \mathrm{W}$ in the sub-prefecture of Azaguié, $25 \mathrm{~km}$ from Abidjan (Ivory Cost). For reproduction, 168 broodstock of the Brazilian strain of Nile tilapia, Oreochromis niloticus were used. A sex ratio of 2:1 with 56 males $(252 \pm 16.81 \mathrm{~g})$ for 112 females $(114.5 \pm 8.58$ g) were used in a breeding happa $(6 \times 4.7 \times 1 \mathrm{~m})$ set up with Chinese bamboo in a $350 \mathrm{~m}^{2}$ pond. The happas are cages made with small mesh polyethylene nets (1 mm empty mesh). Larvae were harvested every 14 days. Harvesting consisted in narrowing the surface of the breeding happa, in order to group all the larvae produced. The larvae, thus, concentrated on the surface of the water were taken, using a net of $1 \mathrm{~mm}$ of mesh with vacuum. Before the recharging of the breeding happa, the females were examined individually, in order to spit out those that still have eggs. The average weight of a larva was determined using samples of three batches of 200 larvae counted with small plastic spoons in plastic bowls. Each batch of larvae was then weighed using a YP 3002 scale with a capacity of $300 \mathrm{~g}$ and a precision of $0.01 \mathrm{~g}$. The biomasses obtained allowed us to determine the average weight of a larva. From this average weight $(0.012 \mathrm{~g})$ a biomass of $17 \mathrm{~g}$ corresponding to 1500 larvae per happa was established. Thus, four batches of larvae were constituted in triplicate, at a rate of 3 per ration rate. Each batch was put in a happa of $1 \mathrm{~m}^{2}$, that is to say 12 happas in total. Each lot corresponds to a density of 1500 larvae $/ \mathrm{m}^{2}$. All 12 happas were installed in a $300 \mathrm{~m}^{2}$ pond. A total of 18.000 larvae with an average initial weight of $0.012 \pm 0.005 \mathrm{mg}$ and a total initial length of $9 \pm 0.003 \mathrm{~mm}$ were used.

\section{B. Rationing Rate and Feeding of Experimental Batches}

The trial lasted 28 days and consisted in testing 4 rationing rates according to the biomass of the fry. The different batches constituted according to the rationing are as follows:

Batch 1: 50, 40, 30 and 25\% of biomass, Batch 2: 40, 30, 25 and $20 \%$ of the biomass, Batch 3: 30, 25, 20 and $18 \%$ of the biomass, Batch 4: 25, 20, 18 and $15 \%$ of biomass.

The different rationing rates were tested during the 1 st, 2nd, 3rd and 4th week of rearing, respectively. Each treatment batch was conducted in triplicate. A density of 1500 fry $/ \mathrm{m}^{2}$ was applied for all treatments. Rations were fed six times per day at the following times 8:00 a.m., 10:00 a.m., 12:00 p.m., 2:00 p.m., 3:00 p.m., and 4:00 p.m. [15] with Raanan feed presented as a $48 \%$ protein flour with a diameter of 0.3 to $0.5 \mathrm{~mm}$. The feed was mixed with the hormone at 60 mg 17- $\alpha$-methyltestosterone/kg feed [16].

C. Monitoring of Physico-chemical Parameters of the Rearing Environment

During the experimentation, the physico-chemical parameters were measured in situ three times a week and twice a day, between 6:30 a.m. and 7:00 a.m. and between 3:30 p.m. and 4:00 p.m. in each happa, using a Handy Polaris model OXYGUAR oximeter for dissolved oxygen and temperature, a WTW model pH $330 \mathrm{pH}$ meter for $\mathrm{pH}$, and a Secchi disk of $30 \mathrm{~cm}$ diameter for transparency.

\section{Calculation and Evaluation of Zootechnical Parameters}

Weekly weight growth checks were conducted on $10 \%$ of the reared population. These controls allowed to adapt the feeding rate to the new biomass obtained. At the end of the 28 days of rearing for each treatment, the biomass of fish from each happa was determined. Then, 30 randomly selected individuals from each treatment were measured for total length and individually weighed to the nearest gram [17].

From the collected data, survival rate (SR), mean weight final (MWF), daily growth (DG), condition factor $(\mathrm{K})$ and Food converion ratio (FCR) were determined with the following mathematical formulas:

$$
\begin{gathered}
S R(\%)=\frac{\text { Number of fish harvested }}{\text { Number of fish stocked }} \times 100 \\
M W F(g)=\frac{\text { Weight of all fish }(g)}{\text { Number of fish }}
\end{gathered}
$$

$$
\begin{aligned}
& D G(g) \\
& =\frac{\text { Average final weight }(g)-\text { Average initial weight }(g)}{\text { Rearing time }(d)} \\
& K=\frac{\text { Final weight }(g)}{(\text { Final length }) 3(\mathrm{~cm})} \times 100 \\
& F C R=\frac{\text { Feed intake }(g)}{\text { Fish weight gain }(g)}
\end{aligned}
$$

\section{E. Statistical Analysis}

The results are presented as mean \pm standard deviation. The zootechnical parameters (final weight, average daily gain, specific growth rate, nutrient quotient and condition factor) were subjected to the one-criteria analysis of variance (ANOVA 1). This test was followed by Tukey's multiple comparison test for parameters with a significant difference ( $p$-value $<0.05)$ in order to identify specific differences between batches taken in pairs. Survival rate was subjected to contingency table analysis. These analyses were performed using STATISTICA 7.1 software.

\section{RESULTS}

\section{A. Physico-chemical Parameters of the Rearing Environment}

The mean values of temperature, $\mathrm{pH}$, dissolved oxygen and transparency are respectively $29.99 \pm 0.41{ }^{\circ} \mathrm{C} ; 7.09 \pm 0.30$; $4.07 \pm 0.60 \mathrm{mg} / 1$ and $41.51 \pm 3.14 \mathrm{~cm}$. The physico-chemical parameters recorded, show that the environments are not significantly (Anova; $p$-value $>0.05$ ) different. 
B. Study of the Rationing Rate of O. niloticus larvae during the Treatment Period with 17- $\alpha$-methyltestosterone (MT)

After 28 days of rearing Nile tilapia Oreochromis niloticus fry subjected to different food treatments, the following results were recorded.

Values preceded by \pm signs represent standard deviations of triplicates. Values with the same alphabetical letters on the same row of the table are not significantly different at the 0.05 level.

Batch 1 (50, 40, 30, and 25\% of biomass); batch 2 (40, 30, 25 , and $20 \%$ of biomass); batch $3(30,25,20$, and $18 \%$ of biomass); and batch 4 (25, 20, 18 , and $15 \%$ of biomass $)$ of fry on the 1st, 2nd, 3rd, and 4th week of feeding, respectively.

TABLE I: ZOOTECHNICAL PARAMETERS OF BRAZIL STRAIN FINGERLINGS OF NILE TILAPIA OREOCHROMIS NILOTICUS

\begin{tabular}{ccccc}
\multicolumn{4}{c}{ UNDERGOING MASCULINIZATION AND SUBJECTED TO DIFFERENT FEEDING RATES FOR 28 DAYS } \\
\hline Parameters & Batch 1 & Batch 2 & Batch 3 & Batch 4 \\
\hline Average initial weight (g) & $12 \pm 0.5$ & $12 \pm 0.5$ & $12 \pm 0.5$ & $12 \pm 0.5$ \\
Survival rate (\%) & $94.89 \pm 1.65^{\mathrm{a}}$ & $91.39 \pm 1.22^{\mathrm{a}}$ & $92.23 \pm 1.61^{\mathrm{a}}$ & $91.07 \pm 6.46^{\mathrm{a}}$ \\
Average final weight (g) & $0.879 \pm 0.116^{\mathrm{ab}}$ & $1.092 \pm 0.027^{\mathrm{b}}$ & $0.980 \pm 0.041^{\mathrm{ab}}$ & $0.823 \pm 0.132^{\mathrm{a}}$ \\
Daily growth (g/d) & $0.030 \pm 0.004^{\mathrm{ab}}$ & $0.038 \pm 0.000^{\mathrm{b}}$ & $0.034 \pm 0.001^{\mathrm{ab}}$ & $0.028 \pm 0.004^{\mathrm{a}}$ \\
Condition factor & $1.53 \pm 0.01^{\mathrm{a}}$ & $1.58 \pm 0.02^{\mathrm{a}}$ & $1.58 \pm 0.01^{\mathrm{a}}$ & $1.56 \pm 0.03^{\mathrm{a}}$ \\
Food converion ratio & $1.57 \pm 0.22^{\mathrm{b}}$ & $0.88 \pm 0.02^{\mathrm{a}}$ & $0.9 \pm 0.03^{\mathrm{a}}$ & $1.06 \pm 0.29^{\mathrm{a}}$ \\
\hline
\end{tabular}

\section{1) Survival rate}

During this experiment, the survival rate ranged from 91.07 to $94.89 \%$ for all treatments (Table I). The value of this parameter was higher for batch 1 and lower for batch 4 . The survival rate values obtained showed no significant difference (Contingency Table; $p$-value $>0,05$ ) from one rationing rate to another.

\section{2) Average final weight and daily growth}

At the end of 28 days of feeding, the final average weight and daily growth recorded in fry during treatment (Table I) is $0.879 \pm 0.116 \mathrm{~g}$ and $0.030 \pm 0.004 \mathrm{~g} / \mathrm{d} ; 1.092 \pm 0.027 \mathrm{~g}$ and $0.038 \pm 0.000 \mathrm{~g} / \mathrm{d} ; 0.980 \pm 0.041 \mathrm{~g}$ and $0.034 \pm 0.001 \mathrm{~g} / \mathrm{d}$ and $0.823 \pm 0.132 \mathrm{~g}$ and $0.028 \pm 0.004 \mathrm{~g} / \mathrm{d}$ for batches $1,2,3$, and 4 respectively. The highest values $(1.092 \pm 0.027 \mathrm{~g}$ and $0.038 \pm 0.000 \mathrm{~g} / \mathrm{d}$ ) of these parameters were recorded in batch 2 fed at 40, 30, 25 and $20 \%$ of their biomasses respectively in the $1 \mathrm{st}, 2 \mathrm{nd}, 3 \mathrm{rd}$ and 4 th week of rearing. The lowest values $(0.823 \pm 0.132 \mathrm{~g}$ and $0.028 \pm 0.004 \mathrm{~g} / \mathrm{d})$ were observed in batch 4 fed at 25, 20, 18 and $15 \%$ of their biomass respectively during the 1 st, 2 nd, 3rd and 4 th week of the trial. Comparison of these parameters reveals a significant difference (Anova; $p$-value < 0.05) from one batch to another. Multiple comparison of means (Tukey's LSD test) shows that the final average weight and daily growth of fry in batch 2 differed significantly $(p$-value $<0.05)$ from those of the other treatment batches.

The variation in mean weight of fry of Brazil strain of Nile tilapia Oreochromis niloticus as a function of the batches tested during 28 days of rearing in happa is shown in Fig 1.

Batch 1 (50, 40, 30 and $25 \%$ of biomass); batch 2 (40, 30, 25 and $20 \%$ of biomass); batch $3(30,25,20$ and $18 \%$ of biomass) and batch 4 (25, 20, 18 and $15 \%$ of biomass) of fingerlings on the 1st, 2nd, 3rd and 4th week of feeding respectively.

\section{1) Condition factor}

The condition factor (Table I) ranged from 1.53 to 1.58 for all treatments. This parameter varied slightly from batch to batch. The highest condition factor was observed in the fry of lot 3 fed at 30,25, 20 and $18 \%$ of their biomass in the 1 st, 2nd, 3rd and 4th week of rearing respectively. The lowest value of this parameter is recorded in batch 1 fry during the 1 st, 2nd, 3rd and 4th week of feeding at 50, 40, 30 and $25 \%$ of biomass respectively. The one-way analysis of variance shows no significant difference $(p$-value $>0.05)$ between the different values of the condition factor obtained for all treatments.

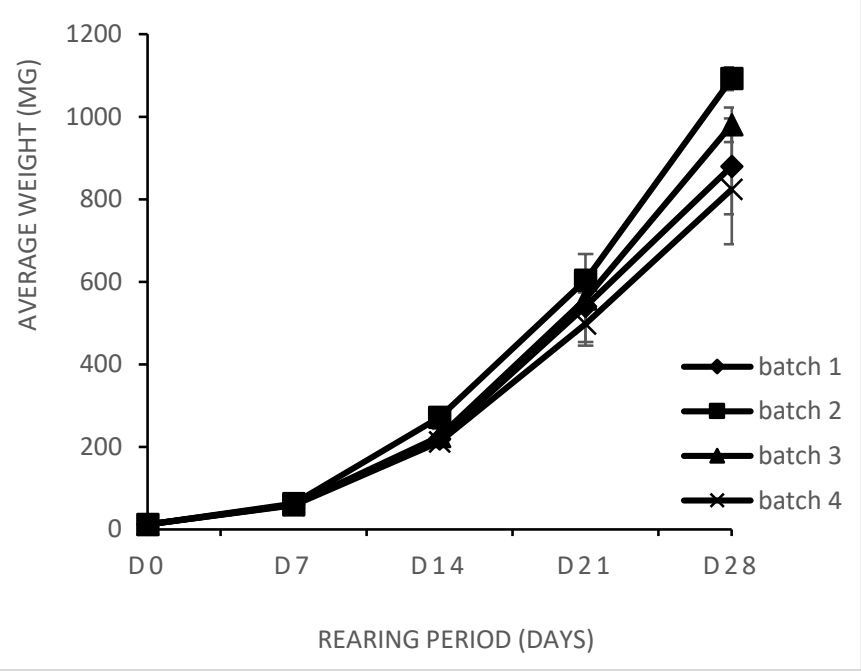

Fig. 1. Variation in mean weight of Brazil strain fry of Nile tilapia Oreochromis niloticus during masculinization subjected to different ration rates as a function of rearing days.

Vertical bars represent differences between triplicates.

\section{2) Food converion ratio}

The food consumption index (Table I) shows values that vary from 0.88 to 1.57 depending on the treatment. The highest value (1.57) of this parameter was obtained in the fry of batch 1 , fed at 50, 40, 30 and $25 \%$ of their biomass per day during the 1 st, 2 nd, 3rd and 4th week of rearing monitoring respectively. The lowest value (0.88) was recorded in individuals of batch 2, rationed at 40,30, 25 and $20 \%$ of their biomass per day during the 1st, 2nd, 3rd and 4th week of rearing respectively. The one-factor analysis of variance showed a significant effect $(p$-value $<0.05)$ of rationing rate on feed intake index. Multiple comparison of means (Tukey's HSD test) showed that batch 1 differed significantly from the other batches (2, 3 and 4). 


\section{DisCUSSION}

The average values of physico-chemical parameters (temperature, dissolved oxygen, $\mathrm{pH}$ and transparency) determined during this study in happas are within the recommended ranges for rearing Nile tilapia Oreochromis niloticus [18], [19]. Thus, the variation in growth performance and feed conversion rate of individuals in all batches was not affected by abiotiotic parameters.

The survival rates obtained in this trial ranged from 91.07 to $94.89 \%$ and from 83.78 to $87.64 \%$, respectively. The values of this parameter are high and are not affected by the variations of the feeding rate applied in the present study. The highest values of this parameter were recorded in individuals fed with high ration rates. Similar results were reported by [20]. These authors found an improvement in the survival rate of tilapia Oreochromis mossambicus fry with an increase in the level of feeding rate from 6 to $24 \%$ of body weight per day. However, the mortalities recorded during the rearing periods could be the result of manupulations during the weekly control fisheries. Overall, the survival rates observed during the two rearing periods were within the normal range ( $\geq 75 \%$ ) for pond culture of Nile tilapia [21]. Regarding the growth parameters (final average weight, daily growth and specific growth rate), the fry of batch 4 (Pmi: 0,012 g) fed at $25 ; 20 ; 18$ and $15 \%$ of their biomass/day show the significantly lower growth performance than those obtained in batch 2 fed with the feed rations of $40 ; 30 ; 25$ and $20 \%$ of their biomass/day during the same feeding period. The results of the present study show that growth parameters improved with increasing feeding rates. These results are in agreement with those reported by [22]. Indeed, this author observed an improvement in the growth of Nile tilapia $O$. niloticus fingerlings with an increase of up to $30 \%$ of the feeding rate. Similar results were also reported by [23]. These authors found improved growth of Nile tilapia fingerlings with an increase in the ration rate to $65 \%$ of body weight/day. They obtained an optimal ration of 30-45\% of biomass per day for Nile tilapia O. niloticus fry. However, [22] reports that increasing the ration rate beyond $30 \%$ does not result in any improvement in fish growth. Indeed, an increase in feeding rate generally results in a significant improvement in growth to a level of stability [24]. In the present study, feed rations of $25,20,18$ and $15 \%$ of biomass fed respectively at 1 st, 2 nd, 3rd and 4th in batch 4 during the rearing period induced the lowest growth. The low growth observed in the fry of batch 4 could be the result of the amount of feed offered by these different ration rates. These rations probably proved to be insufficient to meet the basic dietary requirements of tilapia Oreochromis niloticus fry. Furthermore, beyond the rationing rate of $40 ; 30 ; 25$ and $20 \%$ of biomass per day during the 1 st, 2nd, 3rd and 4th week of feeding respectively, no significant improvement in growth was observed in Nile tilapia fry $(0.012 \mathrm{~g})$. Thus, fry $(0.012 \mathrm{~g})$ astriented at the highest feeding rates of $50 ; 40 ; 30$ and $25 \%$ of body weight/day during the $1 \mathrm{st}, 2 \mathrm{nd}, 3 \mathrm{rd}$ and 4 th week of feeding respectively recorded a decrease in growth performance. This decrease in growth when the food ration exceeds the maximum value, could be explained by a lack of appetite in an environment oversaturated with food [25]. This phenomenon could also be explained by an imbalance between the optimum feeding rate and the stocking density of the fish in the happas. Indeed, if the stocking density is lower or higher than the optimal density, there is wastage and underfeeding of fish. This leads to poor feed utilization resulting in low feeding efficiency [26]. The rationing rates established during this rearing period show a variation in growth according to the level of rationing. Indeed, according to [27], the efficiency of the transformation of an artificial feed depends on the quality and quantity of the feed consumed. Thus, the results of this study will allow a rational management of the feed for an optimal growth of the fry. However, for [28], in a profit-oriented economic context, a better knowledge of fish rationing allows minimizing or maximizing their growth.

\section{CONCLUSION}

At the end of this study, it appears that fry growth improves with increasing feeding rate until an optimal level beyond which no growth is observed. These results show that for an improvement of fry production, an optimal feeding rate of 40 , 30,25 and $20 \%$ of the fry biomass during the 1st, 2 nd, 3rd and 4th week of rearing respectively should be applied in order to avoid either wastage or underfeeding of the subjects during hormone treatment.

\section{REFERENCES}

[1] N. Wing-keong, Potencial of palm oil utilization in aquaculture feeds. Asia Pacific Journal of Clinical Nutrition, vol. 11, n. 7, pp. 473-476, 2002.

[2] R. Devlin, and Y. Nagahama, Sex determination and sex differentiation in fish: an overview of genetic, physiological, and environmental influences. Aquaculture, vol. 208, n. 3-4, pp. 191-364, 2002.

[3] R. A. Bombardelli, C. Hayashi, F. Meurer, and D. C. Fornari, Masculinização de larvas de tilápia do Nilo (Oreochromis niloticus) por banhos de imersão e o andrógeno dissolvido em solução de dimetilsulfóxido (DMSO). Acta Scientiarum Animal Science, vol. 26, n. 2, pp. 209-215, 2004.

[4] C. Rougeot, C. Prignon, C. V. Kengne, and C. Melard, Effect of high temperature during embryogenesis on the sex differentiation process in the Nile tilapia, Oreochromis niloticus. Aquaculture, vol. 276, n. 1-4, pp. 205-208, 2008

[5] R. A. Bombardelli, and Hayashi C, Masculinization of larvae of Nile tilapia (Oreochromis niloticus L.) by immersion baths with alphamethyltestosterone. Revista Brasileira de Zootecnia, vol. 34, n. 2, pp. 365-372, 2005.

[6] A. F. M. El-Sayed, Tilapia culture, CABI Publishing Wallingford Oxfordshire, UK, pp. 1, 2006.

[7] E. T. D. Mensah, F. K. Attipoe, and M. A. Johnson, Effect of different stocking densities on growth performance and profitability of Oreochromis niloticus fry reared in hapa-inpond system. International Journal of Fish. Aquaculture, vol. 5, n. 8, pp. 204-209, 2014.

[8] F. Meurer, C. Hayashi, L. M. Barbero, L. D. Santos, R. A. Bombardelli, et L. M. S. Colpini, Farelo de soja na alimentação de tilápias-do-nilo durante o período de reversão sexual. Revista Brasileira de Zootecnia, vol. 37, n. 5, pp. 791-794, 2008.

[9] Y. S. Al-Hafedh, and S. A. Ali, Effets de l'alimentation sur la survie, le cannibalisme, la croissance et la conversion alimentaire du poissonchat africain, Clarias gariepinus (Burchell) dans des réservoirs en béton. Journal of Applied Ichthyology, vol. 20, n. 3, pp. 225-227, 2004.

[10] C. R. Silva, L. C. Gomes, et F. R. Brandão, Effet du taux et de la fréquence d'alimentation sur la croissance, la production et les coûts d'alimentation du tambaqui (Colossoma macropomum) pendant la première phase de croissance en cage. Aquaculture, vol. 264, n. 1-4 pp. 135-139, 2007.

[11] G. Wu, I. P. Saoud, C. Miller, and D. A. Davis, The effect of feeding regimen on mixedsize pond-grown channel catfish, Ictalurus punctatus. Journal of Applied Aquaculture vol. 15, pp. 115-125, 2004.

[12] J. C. Philippart, and C. Mélard, La production de tilapias en eau chaude industrielle en Belgique. Situation actuelle du projet, perspectives de développement en pisciculture solaire et transfert de la technologie. Cahiers d'Éthologie Appliquée, vol. 7, pp. 107-134, 1987. 
[13] C. Mélard, Les bases biologiques de l'elevage intensif du Tilapia du Nil, recherches sur la biologie de Oreochromis niloticus L. (Pisces Cichlidae) en élevage expérimental: reproduction, croissance, bioénergétique. Cahiers d'Etholgie Appliquee, vol. 10, pp. 224, 1986.

[14] Y. Bamba, A. Ouattara, et G. Gourène, Production d'alevins de Tilapia (Oreochromis niloticus L., 1758) nourris avec des sous-produits agricoles, sans adjonction de farine de poisson. Agronomie Africaine, vol. 19, n. 2, pp. 211-221, 2007.

[15] C. Z. Bi Ué, I. N. Ouattara, et S. Berté, Effets de la fréquence de nourrissage sur les paramètres zootechniques et le taux de masculinisation des larves de la souche «Brésil» du tilapia du nil Oreochromis niloticus (Linnee, 1758) pendant et après le traitement... Agronomie Africaine, vol. 31, n. 3, pp. 259-271, 2019.

[16] T. P. Barry, A. Marwah, and P. Marwah, Stability of $17 \alpha-$ methyltestosterone in fish feed. Aquaculture, vol. 271, n. 1-4, pp. 523529, 2007.

[17] K. Tigoli, M. Cisse, M. Kone, M. Ouattara, A. Ouattara, et G. Gourène, Comparaison des performances de croissance de la souche «Bouaké " de Oreochromis niloticus traités au 17- $\alpha$-methyltestosterone et leurs rentabilités, dans trois structures d'élevage. International Journal of Innovation and Applied Studies, vol. 20, pp. 493-499, 2017.

[18] J. Lazard, La pisciculture des tilapias. Cahiers Agricultures, vol. 18, n. 2-3, pp. 82-174, 2009.

[19] M. S. Azaza, A. Assad, W. Maghrbi, and M. El-Cafsi, 2013. The effects of rearing density on growth, size heterogeneity and inter-individual variation of feed intake in monosex male Nile tilapia Oreochromis niloticus L. Animal; vol. 7, n. 11, pp.1865-1874.

[20] D. J. Macintosh, and S. S. De Silva, The influence of stocking density and food ration on fry survival and growth in Oreochromis mossambicus and reared in a closed circulated system. Aquaculture, vol. 41, pp. 345-358, 1984.

[21] J. S. Diana, C. K. Lin, and K. Jaiyen, Supplemental feeding of tilapia in fertilized ponds. Journal of the world aquaculture society, vol. 25 , n. 4, pp. 497-506, 1994.

[22] A. M. F. El-Sayed, Effects of Stocking Density and Feeding Levels on Growth and Feed Efficiency of Nile Tilapia (Oreochromis niloticus) Fry. Aquaculture Research, vol. 32, pp. 621-625, 2002.

[23] C. B. Santiogo, M. B. Aldada, and O. S. Reyes, Influence of feeding rate and diet form on growth and survival of Nile tilapia (Oreochromis niloticus) fry. Aquaculture, vol. 64, pp. 277-282, 1987.

[24] H. Hogendoorn, J. A. J. Jansen, W. J. Koops, M. A. M. Machiels, P. H. Van Ewijk and J. P. Van Hees, Growth and production of the African catfish, Clarias lazera (C. \& V.): II. Effects of body weight, temperature and feeding level in intensive tank culture. Aquaculture, vol. 34, n. 3-4, pp. 265-285, 1983.

[25] Z. J. Otémé, and S. Gilles, Elevage larvaire du silure africain Heterobranchus longifilis : évaluation quantitative des besoins en proies vivantes des larves. Aquatic Living Resources, vol. 8, pp. 351354, 1995.

[26] M. Jobling, Physiological and social constraints on growth of fish with special reference to Arctic charr, Salvelinus alpinus L. Aquaculture, vol. 44, n. 2, pp. 83-90, 1985

[27] G. Delincé, The ecology of fish pond ecosystem with special reference to Africa. Kluwer Academic Publishers, Dordrecht, the Netherlands, $230 \mathrm{p}, 1992$.

[28] C. Y. Cho, Feeding systems for rainbow trout and other salmonids with reference to current estimate of energy and protein requirement, Aquaculture, 100 : 107-123, 1992. 